\title{
ENTREPRENEURSHIP ORIENTATION AND INNOVATION CAPABILITY: THE ROLE OF INTELLECTUAL RESOURCES AS MEDIATION (A CASE STUDY OF SMES FURNITURE IN MADIUN EAST JAVA)
}

\author{
Ardianus Laurens Paulus ${ }^{* 1}$ \\ *) Faculty of Economic and Business, Universitas Katolik Widya Mandala Madiun \\ Jl. Manggis No.15-17, Madiun, 63131
}

\begin{abstract}
The utilization of intellectual resources in business is growing rapidly today. It is characterized by creative ideas emerging from organizations and companies that are competing in all areas. This research aims to examine the influence of entreprenuership orientation toward innovation capability mediating by intellectual resources. This research employs a quantitative approach using survey method. Data collection was conducted at 61 Small and Medium Enterprises (SMEs) Furniture located in Madiun area, East Java from February to July 2017. The data were analyzed using measurement model of structural equation modeling supported by partial least square (PLS) 3.0 software. This study shows that entrepreneurship orientation has a positive and significant effect on intellectual resources and innovation capability, while the influence of intellectual resources has no effect on innovation capability. The result of mediation testing of intellectual resources as mediator between entrepreneurship orientations and innovation capability is not proven in this research.
\end{abstract}

Keywords: intellectual resources, entrepreneurship orientations, innovation capability, furniture, PLS

Abstrak: Pemanfaatan sumberdaya intelektual di dunia usaha sangat berkembang pesat saat ini. Hal ini ditandai dengan ide-ide kreatif yang muncul dari organisasi maupun perusahaan yang sedang berkompetisi di semua bidang. Penelitian ini bertujuan untuk menguji pengaruh orientasi kewirausahaan terhadap kapabilitas inovasi yang dimediasi oleh sumberdaya intelektual. Pendekatan dalam penelitian ini menggunakan pendekatan kuantitatif dengan metode survei. Penelitian ini dilakukan dengan menguji hipotesis yang telah dikembangkan berdasarkan teori sumberdaya intelektual, orientasi kewirausahaan dan kapabilitas inovasi sebelumnya. Penelitian ini menggunakan data primer yang berupa self report menggunakan self-administered survey yaitu dengan cara menyebarkan kuesioner secara langsung kepada para responden yakni pemilik UKM Mebel di Wilayah Madiun Jawa Timur sebanyak 61 UKM Mebel selama bulan februari hingga juli 2017. Analisis data dilakukan dengan menggunakan model pengukuran persamaan struktural dengan bantuan software partial least square (PLS) 3.0. Penelitian ini menunjukkan bahwa orientasi kewirausahaan berpengaruh positif dan signifikan terhadap sumberdaya intelektual serta kapabilitas inovasi. Sedangkan pengaruh sumberdaya intelektual tidak berpengaruh terhadap kapabilitas inovasi. Hasil uji mediasi sumberdaya intelektual sebagai pemediasi diantara orientasi kewirausahaan dengan kapabilitas inovasi tidak terbukti dalam penelitian ini.

Kata kunci: sumberdaya intelektual, orientasi kewirausahaan, kapabilitas inovasi, mebel, PLS

\footnotetext{
${ }^{1}$ Corresponding author:

Email: ardianus@staff.widyamandala.ac.id.
} 


\section{INTRODUCTION}

The utilization of intellectual resources in the business is growing rapidly today. It is characterized by creative ideas emerging from organizations and companies that are competing in all areas. Intellectual resources are also seen as the most valuable asset in the company and is a source of innovation. Organizations with intellectual capital have characteristics and abilities that can enhance the company's reputation and achievements so that the company needs to continually improve its innovative capabilities in increasingly fierce competition era. Appropriate actions and decisions are needed in innovation process to achieve success in innovation. In order for the innovation process to occur well, the intellectual resources considered by some researchers i.e. Zerenler et al. (2008), Lin et al. (2009), Ngah and Ibrahim (2009) can support to improve the innovation capability. Intellectual resources according to Bontis et al. (2000); Bontis and Fitz-enz (2002) consist of human capital, structural capital and customer's capital. Intellectual resources are the capabilities possessed by the company through the knowledge of the organization members in generating creative ideas to achieve the success and objectives of the organization and to contribute significantly to the company stakeholders. In addition, intellectual resources also need to be considered in order to realize the entrepreneurial spirit of individuals in the company. With the entrepreneurial spirit it will create an entrepreneurship orientation and encourage individuals to generate creativity through their own intellectual capital to achieve success while developing organizations to enhance innovation capability.

Aspects of entrepreneurship orientation strongly support organizations to achieve innovation (Madhoushi et al. 2011). It is based on the company's proactive attitude and courage in taking the risky decision to be one of the deciding factors in the success and improvement of the company's innovation capability. Creative and innovative attitudes are indispensable in the business environment because the ever-changing environment conditions require companies to find new ways in their business processes to stay profitable. The activity of innovation is how to implement new knowledge, ideas, or activities into the company. When companies want to innovate, not only knowledge (intellectual) but also an action and the right decision to innovate are required. Decision making, actions, and behavior of a company are closely related to entrepreneurial activity that refers to the company entrepreneurship orientation (Kraus et al. 2011). Therefore, entrepreneurship orientation itself will affect the overall behavior of the company and become a mindset for the company so that the entrepreneurship orientation has an influence on company's innovation capability.

According to the findings of Abhayawansa and Abeysekera (2008), the intellectual resources of human capital in the company can have a positive impact because human capital is the driving force of the economy, competition and prosperity. The ability of people to apply knowledge and skills is an important element that can improve the ability of behavior and selfdevelopment. Based on the results of research Sharabati et al. (2010), the existence of well-managed internal resources can make the organization more developed. It is expected that the company entrepreneurship orientation, as well as the ability to take action to promote the organization can have an impact on the intellectual resources of the organization.

Based on the research conducted by Rauch et al. (2006) on entrepreneurs in China and Germany, there is a positive relationship between the entrepreneurship orientation and the innovation made by the business actors. Furthermore, when a company is able to identify existing opportunities and dare to take risks, it can support the company's creativity in developing new products as well as implementing a new technology or procedure into the company's internal system. It is reinforced by the results of research conducted by Madhoushi et al. (2011) in small and medium industries which also showed significant results between entrepreneurship orientation and innovation. Entrepreneurship orientation is an approach that focuses on innovation and tend to be a pioneer in innovating. When a company has an entrepreneurship orientation, the process and frequency of innovation will get better and the results will be more effective for the company. Terzioski (2010) and Lin et al. (2009) research on innovation focuses only on the process of sharing knowledge to acquire intellectual resources aimed at enhancing the company's innovation capability because basically the innovation activity is how to implement knowledge, or new activity into the company. Research conducted by Zerenler et al. (2008) states that if the company wants to be innovative, companies need to interact and share knowledge and ideas with others so that an understanding of the customer and the individuals within an organization can be created properly. From 
the results of research conducted by Ngah and Ibrahim (2009), it is also known that the intellectual resources are necessary to improve the company's innovation capability. The experience and creativity possessed by individuals within a company need to be disseminated and integrated with the knowledge possessed by other individuals so that the company can develop new processes, services, and products. Companies that encourage their employees to contribute to knowledge sharing in groups or companies, tend to generate new ideas and develop new business opportunities through innovation activities. The ability of companies to acquire new knowledge related to intellectual resources is needed to innovate because with new knowledge the company gets new information that will be integrated with existing knowledge and then applied into the company. Thus, the capability of innovation will be achieved if the company can utilize the intellectual resources properly and maximally.

According to Ngah and Ibrahim (2009), entrepreneurship orientation plays an important role in generating innovation capability but orientation needs to be harmonized with intellectual resources owned by the organization so that the goals and sustainability of the organization can be achieved well and at the same time can grow up.

This study takes place in the small and medium enterprises (SMEs) sector engaged in the furniture. SMEs are one of the industries that contribute to the economic in many areas in Indonesia. SMEs furniture sector is an industry that also uses intellectual resources in carrying out its activities. With the intellectual resources owned by SMEs furniture then a lot of creativity that can bring innovation in SMEs furniture. However, the entrepreneurship orientation in SMEs furniture should be considered because the uniqueness in furniture business is the creative ideas that arise in the process of product creation and art of carving. The entrepreneurship orientation can determine the benefits of furniture companies in creating new innovations because through innovation, culture and local wisdom in Indonesia can be shown continuously and can be a special feature of the SMEs furniture.

The new arising innovations are due to the intellectual resources possessed by the furniture company in building a good relationship through the knowledge possessed by the individual within the furniture organization with others. In addition, entrepreneurship orientation is crucial for the ability to innovate in the SMEs furniture sector, but the role of intellectual resources owned by the furniture company is very important to create the progress and sustainability of the furniture companies. Thus, SMEs furniture that needs to move forward and compete must have a high entrepreneurship orientation and have good intellectual resources so as to bring about sustainable innovation.

This study aims to examine the influence of entrepreneurship orientation on innovation capability mediated by intellectual resources. This research was conducted in SME furniture in Madiun area of East Java whose respondent is the owner or manager of furniture.

\section{METHODS}

This research is a quantitative approach using a survey method. The sample in this study was determined by using the Part Least Square (PLS) based on the variance so the sample used is not too large (Wong, 2010). The sample was taken by using non probability sampling method with purposive sampling technique (Cooper and Schindler, 2011). The respondents of this research are the SMEs furniture in the Madiun area with the unit of analysis is the owner of 61 SMEs furniture. Respondents of this study have been chosen because the owner or the manager is an individual who knows most about the activities of the furniture business run and resources owned.

The type of data used in this study is the primary data in the form of self-report by using questionnaires (Cooper and Schiendler, 2011). The questionnaire consists of two parts: the first part contains the demographic characteristics of the respondent and the second contains statements of the variables of entrepreneurship orientation, intellectual resources and innovation capability. Questionnaires statements measured on a Likert scale of 1 to 5 . The variables of entrepreneurship orientation, intellectual resources and innovation capability in Table 1 .

Data analysis was done using structural equation measurement model (SEM) with part least square (PLS) approach. Using PLS makes it possible to perform structural equation modeling because the sample size is relatively small and does not require the assumption of multivariate normal (Ghozali, 
2008) which consists of the analysis of outer models of convergent validity, discriminant validity, average variance extracted (AVE), composite reliability, and cronbach alpha (Hair et al. 2010). Then the inner model that is on the structural model is tested to see the relationship of the latent constructs (Ghozali, 2008). There are several tests in the structural model consisting of $\mathrm{R}$ square on endogenous construct and estimate for the path coefficients. $\mathrm{R}$ square value is the coefficient of determination in endogenous construct which is a goodness of fit test, while the estimate for path coefficients is the coefficient value of the path or the extent of the relationship or the influence of latent constructs performed with bootstrapping procedures.

Table 1 . The variables of entrepreneurship orientation, intellectual resources and innovation capability

\begin{tabular}{|c|c|c|c|}
\hline Variabel & & & Explanation \\
\hline \multirow{5}{*}{$\begin{array}{l}\text { Entrepreneurship } \\
\text { Orientation } \\
\text { (OK) (Kreiser et } \\
\text { al. 2002) }\end{array}$} & Looking for new opportunities & OK1 & SMEs are often looking for new business opportunities. \\
\hline & $\begin{array}{l}\text { Introducing new products and } \\
\text { services }\end{array}$ & OK2 & SMEs often recognize new products and services \\
\hline & Act quickly (market response) & OK3 & SMEs are always competitive with competitors. \\
\hline & & OK4 & SMEs tend to get many orders and make a profit. \\
\hline & & OK5 & SMEs dare to act quickly and widely to achieve goals. \\
\hline \multirow{20}{*}{$\begin{array}{l}\text { Intellectual } \\
\text { resources } \\
\text { (SI)(Bontis, 1998; } \\
\text { Bontis et al. } \\
\text { 2000; Bontis and } \\
\text { Fitz-enz, 2002) }\end{array}$} & Human capital was the source of & SI1 & Individuals in SMEs have experience related to their work. \\
\hline & individual creativity, knowledge, & SI2 & Individuals in SMEs have expertise related to their field. \\
\hline & & SI3 & Individuals in SMEs have high motivation in working. \\
\hline & & SI4 & $\begin{array}{l}\text { Individuals in SMEs attend training to increase their skills } \\
\text { and skills. }\end{array}$ \\
\hline & & SI5 & $\begin{array}{l}\text { Individuals in SMEs get decent compensation according to } \\
\text { their work. }\end{array}$ \\
\hline & & SI6 & Individuals in SMEs have high satisfaction. \\
\hline & & SI7 & Individuals in SMEs have a high loyalty. \\
\hline & Structural capital is the & SI8 & Individuals in SMEs are obedient to the leadership. \\
\hline & $\begin{array}{l}\text { development of product/idea } \\
\text { and organizational infrastructure }\end{array}$ & SI9 & $\begin{array}{l}\text { Individuals in SMEs communicate well with each other } \\
\text { well. }\end{array}$ \\
\hline & $\begin{array}{l}\text { related to authority and } \\
\text { responsibility }\end{array}$ & SI10 & Individuals in SMEs know their respective authorities. \\
\hline & & SI11 & $\begin{array}{l}\text { Individuals in SMEs are aware of their respective } \\
\text { responsibilities. }\end{array}$ \\
\hline & & SI12 & $\begin{array}{l}\text { Individuals in SMEs follow all the processes that have been } \\
\text { set. }\end{array}$ \\
\hline & & SI13 & Individuals in SMEs follow all the established procedures. \\
\hline & & SI14 & $\begin{array}{l}\text { Individuals in SMEs adhere to all policies that have been } \\
\text { set. }\end{array}$ \\
\hline & & SI15 & $\begin{array}{l}\text { Individuals in SMEs keep up with the ever-changing } \\
\text { developments. }\end{array}$ \\
\hline & & SI16 & Facilities and infrastructure in SMEs are very supportive. \\
\hline & Customer capital is an & SI17 & SMEs always keep good relationship with customers. \\
\hline & understanding of customer & SI18 & Customers are always satisfied with the products. \\
\hline & network marketing & SI19 & SMEs are always market oriented. \\
\hline & & SI20 & SMEs always know what customers want. \\
\hline \multirow{5}{*}{$\begin{array}{l}\text { Innovation } \\
\text { Capability } \\
(\text { KI)(Terziovski, } \\
2010)\end{array}$} & New ideas, ways, creativity, & KI1 & SMEs often try new ideas \\
\hline & new products and services, & $\mathrm{KI} 2$ & SMEs are trying to find new ways to do things. \\
\hline & & $\mathrm{KI} 3$ & SMEs have creativity in operational matters. \\
\hline & & KI4 & $\begin{array}{l}\text { SMEs are often the first in marketing new products and } \\
\text { services. }\end{array}$ \\
\hline & & KI5 & $\begin{array}{l}\text { The services introduced by SMEs have improved over the } \\
\text { last } 3 \text { years. }\end{array}$ \\
\hline
\end{tabular}


Then the testing of mediation analysis in this study uses references from Baron and Kenny (1986) and McKinnon and Fairchild (2009). In testing the influence of mediation there are three kinds of variables. The three variables are predictor (entrepreneurship orientation $\mathrm{OK}$ ), criterion (innovative capability - KI) and mediator (intellectual resources - SI).

The first stage examines the direct influence of the predictor on the criterion and then proceeds with the second stage of testing the predictor toward the mediator, and the third stage, testing the mediator toward the criterion. The fourth stage is to examine the influence of predictors on the criterion by still including the influence of mediators on the model. The mediation effect consists of three types: (1) full mediation, (2) partial mediation, (3) no mediation. Then hypothesis testing can be seen from t-statistics and probability value. To test the hypothesis, a statistical value with alpha criteria $5 \%(0.05)$ is used, and the value of $\mathrm{t}$-statistics used is 1.96 . Thus, the criteria of acceptance or rejection of hypothesis is $\mathrm{Ha}$ accepted and $\mathrm{HO}$ is rejected when t-statistic $>1.96$. To reject or accept the hypothesis, the probability $\mathrm{Ha}$ is accepted if the value of $p<0.05$ (Ghozali, 2008). However, Wonnacott and Wonnacott (1990) suggest that researchers may also use a $90 \%$ confidence interval with $\alpha=0.10$ to establish error rates in statistical significance testing for social science and behavior.

This research proposes four hypotheses. First, the entrepreneurship orientation has a positive and significant impact on intellectual resources. In realizing an action there needs to be a spirit that is imbued by every individual within an organization. The spirit needs to be based on a broad understanding and knowledge of the actions to be taken so as to achieve organizational goals, because the entrepreneurship orientation will affect the behavior of the company as a whole and become the mindset to support intellectual resources consisting of human capital, structural capital and customer capital. Intellectual resources are the skills, knowledge and talents as well as the experience possessed by the individual (Sharabati et al. 2010).
Second, the entrepreneurship orientation has a positive and significant impact on innovation capability. When companies want to innovate a company requires new actions derived from the organization's process. Then when innovation is implemented, it takes an appropriate action and decision making which is reflected from the entrepreneurship orientation owned by the company. New actions are very important in developing a new product or idea. There is also an orientation or direction strategy for the company to find new opportunities. Therefore, companies with an entrepreneurship orientation can improve its capability and help the company to find new opportunities and then take action in the form of innovation that benefits the companies (Li et al. 2006).

The third, intellectual resources have a positive and significant impact on innovation capability. Intellectual resources are assumed as strategic assets to help companies improve their competitiveness in global competition (Jordon and Martos, 2012). Intellectual resources are also considered as the key to building an innovation process (Lin et al. 2009). With the existence of intellectual resources, a company can increase the creativity and innovation that can be value added for the company.

And the fourth, intellectual resources mediate the influence of entrepreneurship orientation on innovation capability. There are few researches on the role of intellectual resources in mediating the effect of entrepreneurship orientation on innovation capability. Organizations with good intellectual resources can respond to and capture market signals quickly (Bontis et al. 2000). In response to rapid market changes it takes a courageous act to compete and make a breakthrough. The action taken is an action oriented by the company to benefit from the market. It needs synchronization between resources owned by company so that actions taken can give maximum result. In action taken it is necessary to realize the real changes that bring innovation and competitiveness. The research model in Figure 1 shows the theoretical framework on the role of intellectual resources in mediating the effect of entrepreneurship orientation on innovation capability. 


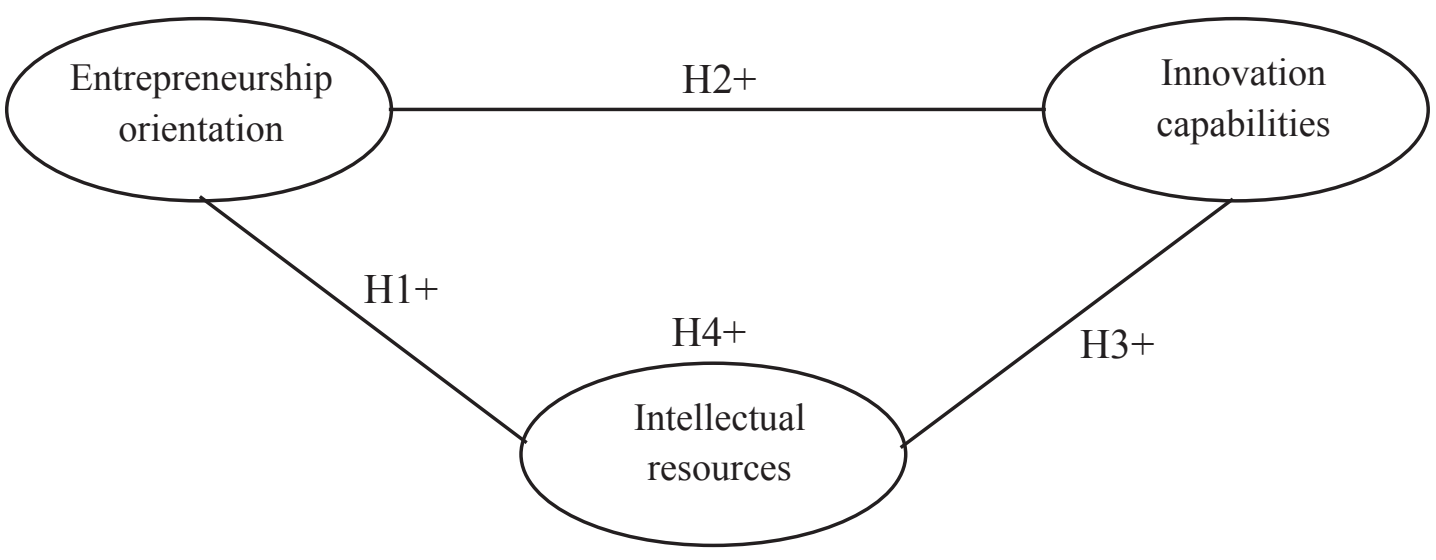

Figure 1. Research framework

\section{RESULTS}

Respondents of this research are SMEs furniture in Madiun whose unit of analysis is the owner or business manager. Characteristics of respondents in this study are based on the age of the business, the term of office managers or owners, gender, and number of workers. In this study, questionnaires are distributed to SMEs furniture in Madiun area in February until July 2017. Included in the study sample was 70 questionnaires based on data from the Department of Industry and Trade of the City of Madiun. However, only a number of qualified and worthy 61 questionnaires were returned to be analyzed.

Based on the results of Table 2, there are 49 male respondents and 12 women. The length of operation of SMEs furniture included in this research sample consists of less than 1 year (4 SMEs furniture) and 57 more than 3 years of operation. Leader or owner period under 1 year ( 1 person), 1 to 3 years ( 3 persons) and more than 3 years (57 persons). The number of labor owned by SMEs furniture consists of 1 to 5 people ( 9 SMEs furniture), 6 to 10 (3 SMEs furniture) and 11 to 15 (3 SMEs furniture). A total of 46 furniture has a labor force of 16 to 20 people.

The outer model analysis is performed to ensure that the measurement used is feasible for measurement (valid and reliable). The tests performed on the outer model consist of convergent validity, discriminant validity, average variance extracted (AVE), composite reliability and cronbach alpha tests. In this study, the AVE value of each construct was above 0.5 which means valid (Hair et al. 2010) (Table 3).
Tabel 2. Characteristics of respondents

\begin{tabular}{lcc}
\hline \multicolumn{1}{c}{ Description } & Amount & Percentage (\%) \\
\hline Gender & & \\
Male & 49 & 80.3 \\
Female & 12 & 19.7 \\
Total & 61 & 100 \\
Business Age (Year) & & \\
$<3$ & 4 & 6.6 \\
$>3$ & 57 & 93.4 \\
Total & 61 & 100 \\
Leader / Owner Period (Year) & \\
$<1$ & 1 & 1.6 \\
$1-3$ & 3 & 4.9 \\
$>3$ & 57 & 93.4 \\
Total & 61 & 100 \\
Number of Labor (Person) & \\
$1-5$ & 9 & 14.8 \\
$6-10$ & 3 & 4.9 \\
$11-15$ & 3 & 4.9 \\
$16-20$ & 46 & 75.4 \\
Total & 61 & 100 \\
\hline
\end{tabular}

Tabel 3. AVE and AVE Square Roots

\begin{tabular}{lcc}
\hline \multicolumn{1}{c}{ Construct } & AVE & $\begin{array}{c}\text { AVE Square } \\
\text { Roots }\end{array}$ \\
\hline $\begin{array}{l}\text { Innovation Capability (KI) } \\
\begin{array}{l}\text { Entrepreneurship Orientation } \\
\text { (OK) }\end{array}\end{array}$ & 0.671 & 0.819 \\
Intellectual resources (SI) & 0.505 & 0.711 \\
\hline
\end{tabular}


Due to the absence of convergent validity problem then the next tested is related to discriminant validity. The method that can be used to test the discriminant validity is to look on the cross loading tables as in the Table 4. The Table 4 shows that the loading value of each item to its construct is greater than its cross loading value that is above 0.5 means there is no problem discriminant validity. From the analysis of cross loading it appears that there is no problem of discriminant validity after items that do not meet the loading value is removed from the model (the initial item in Table 1, and validity test using discriminant validity by seeing cross loading above 0.5 , and the remaining items in Table 4).

In addition, to ensure that there are no problems related to the measurement of the final step in the evaluation of the model, unidimensionality outer of the model is tested. Unidimensionality test is done by using composite indicators and cronbach alpha reliability. For both of these indicators the cut-off value point is 0.6 so that all statement items in the three variables are reliable (Hair et al. 2010). Table 5 shows that all constructs have composite reliability and alpha cronbach values above 0.6. Therefore, there is no reliability or unidimensionality problem in the established model. Inner model analysis or structural model in Table 6 shows the estimation result that the effect of entrepreneurship orientation on innovation capability has a path coefficient of 1.805 where the influence is significant ( $\mathrm{p}$ value $=0.072<0.10$ or sig. $10 \%)$. Entrepreneurship orientation is also a positive influence on the intellectual resources based on the estimation of the regression coefficients with path coefficient of 2.162 (significant: $p$ value $=0.031<0.05$ or $5 \%$ ). Then intellectual resources have no effect on innovation capability based on estimation result on regression coefficient with path coefficient 0,132 (significant: $\mathrm{p}$ value $=0.859>0,10$ or $10 \%$ ).

Testing the influence of mediation can be done by using the theory formulated by Baron and Kenny (1986) and McKinnon and Fairchild (2009). The first stage examines the influence of the predictor on the criterion. In this first step, it appears that Entrepreneurship Orientation (predictor) influences the innovation capability (criterion) ( $\mathrm{p}$ value $=0.072<0.10$ or sig. $10 \%)$.

The second stage is to see if the predictor has an influence on mediators. The second step shows that the predictor (entrepreneurship orientation which consists of OK1,
$\mathrm{OK} 2, \mathrm{OK} 3, \mathrm{OK} 4$ and $\mathrm{OK} 5$ are items that have passed the validity test through discriminant validity with each cross loading that is above 0.5 ) has an influence on mediators (intellectual resources which consists of SI6,SI9, SI11, SI13, SI14, SI15, SI17 and SI20 are items that have passed the validity test through discriminant validity with each cross loading above 0.5$)(\mathrm{p}$ value $=$ $0.031<0.05$ or $5 \%$ ). It is followed by the third stage of the influence of mediators against criterion. In the third stage, the mediator (intellectual resources) has no influence on the criterion (innovation capability which consists of KI1, KI2, KI3 and KI4 are items that have passed the validity test through discriminant validity with each cross loading that is above 0.5$)$ ( $\mathrm{p}$ value $=$ $0.859>0.10$ or $10 \%$ ). To see if the intellectual resources have a mediating effect (full, partial or not) then it can proceed to stage four.

Tabel 4. Cross loadings

\begin{tabular}{cccc}
\hline Construct & $\begin{array}{c}\text { Innovation } \\
\text { Capability } \\
(\mathrm{KI})\end{array}$ & $\begin{array}{c}\text { Entrepreneurship } \\
\text { Orientation }(\mathrm{OK})\end{array}$ & $\begin{array}{c}\text { Intellectual } \\
\text { Resources } \\
(\mathrm{SI})\end{array}$ \\
\hline KI1 & 0.559 & & \\
KI2 & 0.918 & & \\
KI3 & 0.866 & & \\
KI4 & 0.882 & 0.698 & \\
OK1 & & 0.650 & \\
OK2 & & 0.737 & \\
OK3 & & 0.650 & \\
OK4 & & 0.805 & 0.890 \\
OK5 & & & 0.868 \\
SI11 & & & 0.851 \\
SI13 & & & 0.745 \\
SI14 & & & 0.867 \\
SI15 & & & 0.822 \\
SI17 & & & 0.897 \\
SI18 & & & 0.831 \\
SI20 & & & \\
SI6 & & & \\
SI9 & & & \\
\hline
\end{tabular}

Tabel 5. Composite reliability and cronbachs alpha

\begin{tabular}{lccc}
\hline Construct & $\begin{array}{c}\text { Composite } \\
\text { Reliability }\end{array}$ & $\begin{array}{c}\text { Cronbachs } \\
\text { Alpha }\end{array}$ & Description \\
\hline $\begin{array}{l}\text { Innovation } \\
\text { Capability (KI) }\end{array}$ & 0.888 & 0.835 & Reliable \\
$\begin{array}{l}\text { Entrepreneurship } \\
\text { Orientation (OK) }\end{array}$ & 0.835 & 0.761 & Reliable \\
$\begin{array}{l}\text { Intellectual } \\
\text { resources (SI) }\end{array}$ & 0.958 & 0.941 & Reliable \\
\hline
\end{tabular}


Tabel 6. Path coefficients, R-square and hypotheses test

\begin{tabular}{|c|c|c|c|}
\hline & T Statistics & $\mathrm{P}$ Value & Result \\
\hline Entrepreneurship Orientation $\rightarrow$ Innovation Capability & 1.805 & $0.072 *$ & Accepted \\
\hline Entrepreneurship Orientation $\rightarrow$ Intellectual resources & 2.162 & $0.031 * *$ & Accepted \\
\hline Intellectual resources $\rightarrow$ Innovation Capability & 0.132 & 0.895 & Rejected \\
\hline $\begin{array}{ll}\text { R Square } & \text { : Innovation Capability } 0.284(28.4 \%) \\
& \text { : Intellectual resources } 0.539(53.9 \%)\end{array}$ & & & \\
\hline Significant $: t=1.805(\operatorname{sig} .10 \% *): 2.162(\operatorname{sig} .5 \% * *)$ & & & \\
\hline
\end{tabular}

The fourth step is to look at the influence of predictors (entrepreneurship orientation) on criterion (innovation capability) while still including the influence of mediators (intellectual resources). From the test it appears that when the influence of the mediator is included in the model, the mediator variable (intellectual resources) has no significant effect on the innovation capability. Thus, intellectual resources do not mediate the influence of entrepreneurship orientation on innovation capability or, in other words, entrepreneurship orientation has a direct influence on the innovation capability.

In addition, the results of the analysis show that the value of R square (R2) is 0.284 for innovation capability. $28.4 \%$ means that the innovation capability are influenced by variables consisting of entrepreneurship orientation and intellectual resources, while $71.6 \%$ variable innovation capability are influenced by other variables outside variables that are not included in the research model. While for intellectual resources variable, $\mathrm{R} 2$ value obtained is 0.539 . It means $53.9 \%$ that the intellectual resources is influenced by variables entrepreneurship orientation, while $46.1 \%$ variable intellectual resources is influenced by other variables outside variables that are not included in the research model. The value of $\mathrm{R} 2$ obtained over 0.5 indicates that the model's goodness of fit size is good.

Based on the data analysis, the result shows that entrepreneurship orientation has a positive and significant effect on intellectual resources in SME furniture under study. The business furniture's entrepreneurship orientation as well as its ability to take actions that promote a business can have an impact on intellectual resources namely the business furniture itself, the relationship between the owner and the employees, owners and employees of furniture with customers, and the owner of furniture with suppliers. A positive relationship between the entrepreneurship orientation and the intellectual resources will affect the overall behavior of the company and become the mindset for the company to support the intellectual resources comprising human capital, structural capital and customer's capital within the organization itself. Intellectual resources are the expertise, knowledge and talent and experience possessed by the individuals of SMEs furniture under study. The results of this study support the findings of Sharabati et al. (2010) and Abhayawansa and Abeysekera (2008). Companies with an entrepreneurship orientation can enhance the company's capability and help companies to find new opportunities and then take action in the form of innovation that can benefit the company. When SMEs furniture is able to identify existing opportunities and dare to take risks, then it can support the creativity of SMEs furniture in developing new products and implementing a new technology or procedures into the internal company.

The entrepreneurship orientation is one of the SMEs furniture approaches to focus on innovation and the tendency for SMEs furniture to be a pioneer in innovation. This means that when SMEs furniture has an entrepreneurship orientation, the process and frequency of innovation they do will get better and the result will be more effective for SMEs furniture. The results of this study support the findings by Madhoushi et al. (2011), Rauch et al. (2006), and Li et al. (2006). Intellectual resources are assumed to be a strategic asset to help the company improve its competitive ability. Intellectual resources are considered as the key to building an innovation process. However, in this study, intellectual resources have no effect on innovation capability of SMEs furniture studied. Owners of SMEs furniture that became the sample of this research has not been able to implement knowledge, ideas, or new activities into the company so that intellectual resources consisting of human capital, structural capital and customer capital are still not fully exploited by SMEs furniture perpetrators investigated in the ability of corporate innovation. 
Basically the innovation activity is how the company's ability gains new knowledge to innovate because with the new knowledge the company can get new information that can then be integrated with existing knowledge and applied to the company. Thus the innovation capability will be achieved if the company can take advantage of the intellectual resources properly and optimally. The results of this study do not support the notion Ngah and Ibrahim (2009), Zerenler et al. (2008), Terzioski (2010) and Lin et al. (2009). The entrepreneurship orientation plays an important role in generating innovation capability but the entrepreneurship orientation needs to be harmonized with the intellectual resources possessed by the organization so that the goals and sustainability of the organization can be achieved well while creating the ability to innovate.

The entrepreneurship orientation can directly influence innovation capability without intellectual resources. This means that SMEs furniture owner act and generate the innovations they want without looking at their own intellectual resources such as relationships with stakeholders (employees, customers and suppliers). This is because SME furniture under study has not fully improved its innovation capability through its own intellectual resources and only following the way it has done in general.

The ability of SMEs furniture to acquire new knowledge through intellectual resources needs to be improved so that companies's new information can be integrated with existing knowledge and applied into the company to bring innovation.

\section{Managerial Implication}

Some implications that can be used as a reference for the owner of SMEs furniture in Madiun area who became the research sample is; (1) SMEs furniture need to be open to new ideas and need to have the will to try those new ideas to find new ways of doing things creatively through their operational methods as an effort to introduce something new to improve product quality and services and to act quickly and appropriately in response to the market. (2) In addition, the SMEs furniture needs to take full advantage of the intellectual resources that consists of human capital, structural capital and customer capital well and the maximum to achieve the desired innovation. (3) Later,
SMEs furniture actors need to be entrepreneurically oriented strategically in making decisions and actions and being more proactive towards competitors.

\section{CONCLUSIONS AND RECOMMENDATIONS}

\section{Conclusions}

Among the four hypotheses proposed in this study, only two that have a significant and positive effect of entrepreneurship orientation influences on innovation capability and the influence of entrepreneurship orientation onintellectual resource. While the hypothesis that the intellectual resource affect the innovation capability is not proven in this study. Besides, the role of intellectual resource in mediating the effect of entrepreneurship orientation on innovation capability is also not proven in this research. Theoretically, the entrepreneurship orientation and intellectual resource is needed by SMEs furniture in the Madiun area to improve their innovation skills.

\section{Recommendations}

Intellectual resource need to be considered by SMEs furniture because it is a source of creativity and innovation consisting of knowledge, capability, development and behavior in addition to product or idea development and organizational infrastructure related to authority and responsibility, processes and procedures and policies. Then, with an understanding of customer relationships built through network marketing, customer knowledge, market orientation, market intelligence and understanding of consumer behavior.

\section{REFERENCES}

Abhayawansa, Abeysekera. 2008. An explanation of human capital disclosure from the resource based perspective. Journal of Human Resource Costing \& Accounting 12(1): 51-64. https://doi. org/10.1108/14013380810872752.

Baron RM, Kenny DA. 1986. The moderator- mediator variable distinction in social psychological research: conceptual, strategic, and statistical considerations. Journal of Personality and 
Social Psychology 51:1173-1182. https://doi. org/10.1037/0022-3514.51.6.1173.

Bontis N. 1998. Intellectual capital: an exploratory study that develops measures and models. Journal of Management Decision 36(2): 63-76. https://doi.org/10.1108/00251749810204142.

Bontis N, Fitz-enz J. 2002. Intellectual capital ROI: a causal map of human capital antecedents and consequents. Journal of Intellectual Capital 3(3):223-247. https://doi. org/10.1108/14691930210435589.

Bontis N, Keow WC, Richardson S. 2000. Intellectual capital and business performance in Malaysian Industries. Journal of Intellectual Capital 1(1): 2000: 85-100. https://doi. org/10.1108/14691930010324188.

Cooper DR, Schindler PS. 2006. Business Research Methods. 9th Edition New York: McGraw-Hill.

Ghozali I. 2008. Structural Equation Modeling: Metode Alternatif dengan Partial Least Square (PLS). Semarang: Undip.

Hair JF, Anderson RE, Tatham RT, Black WC. 2010. Multivariate Data Analysis, 7th Edition. New Jersey: Prentice Hall, Upper Saddle River, NJ.

Jordon CM, Martos MS. 2012. Intellectual capital as emerging clusters in Latin America. Journal of Intellectual Capital 13(4): 462-481. https://doi. org/10.1108/14691931211276098.

Kraus S, Rigtering JPC, Hughes M, Hosman V. 2011. Entrepreneurial orientation and the business performance of SMEs: a quantitative study from The Netherlands. Review of Managerial Science 6(2):161-182. https://doi.org/10.1007/s11846011-0062-9.

Kreiser PM, Marino LD, Weaver KM. 2002. Assessing the psychometric properties of the entrepreneurial orientation scale: a multi - country analysis. Entrepreneurship Theory and Practice 26(4):71-94. https://doi. org/10.1177/104225870202600405.

Li Y, Liu Y, Zhao YB. 2006. The role of market, entrepreneurial orientation and internal control in the new product development activities of chinese firms. Journal of Industrial Marketing Management 35(3): 336-347. https://doi. org/10.1016/j.indmarman.2005.05.016.

Lin RJ, Chen RH, Chiu KKS. 2009. Customer relationship management and innovation capability: an empirical study. Industrial Management \& Data Systems 110(1):111-133. https://doi.org/10.1108/02635571011008434.

MacKinnon DP, Fairchild AJ. 2009. Current directions in mediation analysis. Current Directions in Psychological Science 18:16-20. https://doi. org/10.1111/j.1467-8721.2009.01598.x.

Madhoushi M, Sadati A, Delavari H, Mehdivand M, Mihandost R. 2011. Entrepreneurial orientation and innovation performance: the mediating role of knowledge management. Asian Journal of Business Management 3(4):310-316.

Ngah R, Ibrahim AR. 2009. The relationship of intellectual capital, innovation and organizational performance: a preliminary study in Malaysian SMEs. International Journal of Management Innovation Systems 1(1):1-13.

Rauch A, Frese M, Wang ZM, Konig C. 2006. A universal contingency approach: innovation, entrepreneurial orientation and peformance in Chinese and German Entrepreneurs. Frontiers of Entrepreneurship Research 26(22).

Sharabati, Abdel-Aziz A, Jawad Shawqi N, Bontis N. 2010. Intellectual capital and business performance in the pharmaceutical sector of Jordan. Management Decision 48(1):105-131. https://doi.org/10.1108/00251741011014481.

Terziovski M. 2010. Innovation practice and its performance implications in Small and Medium Enterprises (SMEs) in the manufacturing sector: a resource-based view. Strategic Management Journal 31: 892-902. https://doi.org/10.1002/ smj.841.

Wong KK. 2010. Handling small survey sample size and skewed dataset with partial least square path modelling. Vue: The Magazine of the Marketing Research and Intelligence Association November, 20-23.

Zerenler M, Hasiloglu SB, Sezgin M. 2008. Intellectual capital and innovation performance: empirical evidence in the turkish automotive supplier. Journal of Technology Management Innovation 3(4):31-40. https://doi.org/10.4067/S071827242008000200003.

Wonnacott TH, Wonnacott RJ. 1990. Introductory Statistics for Business and Economics. 4th Edition. New Jersey: John Wiley \& Sons, Inc. USA. 